\title{
Systematic Review of COVID Spillover and Online Education Pedagogy
}

\author{
Haroon Aziz ${ }^{1}$, Samina Malik², Abdul Ahad ${ }^{3}$ \& Umair Javed ${ }^{4}$ \\ ${ }^{1}$ Independent Researcher, Pakistan \\ ${ }^{2}$ Educationist \& Independent Researcher, Pakistan \\ ${ }^{3}$ Independent Researcher, MJCCS Tarbela, Pakistan \\ ${ }^{4}$ Xian Jiaotong University, Xian China \\ haroonpvma@gmail.com, saminamalik1919@gmail.com, ahadmjccs20@gmail.com, \\ umairgallian0008@gmail.com
}

\begin{abstract}
This paper has touched one of the most critical area affected due to pandemic situation created by the COVID-19 and its powerful spillover effect on education sector by customizing education pedagogy. Earlier researchers have studied online education separately, whereas this paper discussed the natural transition and systematic review of upsurge of e-learning. The objective of this paper is to make the systematic review of COVID spillover and transition towards e-learning education pedagogy through theoretical framework. The study makes systematic review of switchover towards e-learning and spillover effect of COVID-19 and customization of the education pedagogy. In this study, past literature has been utilized to make critical analysis of spillover effect of COVID-19 and impact on education pedagogy by creation of prepositions. The findings of the study reveal that in the exceptional circumstances of COVID-19, e-learning transition has taken place from conventional to e-learning modules. All over the world, countries have shifted towards online education by schooling out but classes in campaign ignited by Chinese government. The same has also been replicated in other countries of the world during COVID-19.
\end{abstract}

Keywords: COVID spillover, online education, pedagogy.

\section{Introduction}

WHO affirmed the outburst of the pandemic Corona virus disease 2019 (COVID-19) on March 12,2020 (Ghebreyesus, 2020). It has closed doors of economies and has led to worst ever crises. The proliferation of pandemic disease has severely affected financial markets, business, organizations as well as education sector (Ozili et al., 2020). UNESCO Director General Audrey Azoulay said that we have never witnessed such educational disruption on such a mega scale. Most of the educational schools, universities as well as other educational institutes have shut their doors and students have to revert back to their parents and have quarantined themselves with their family. Moreover; convocations and graduation ceremonies have also been postponed. Education sector is the backbone of any economy. Moreover, Education is one of the most significant pillars wh0ich ameliorate economic growth. In the exceptional circumstances, stringent measures for emergency e-learning protocols and transition from conventional face to face classes to e-learning modules have started (Murphy, 2020). Chinese government has launched online education campaign by schooling out but classes in (Zhou, Wu, Zhou, \& Li, 2020). The same has also been replicated in other countries of the world during COVID-19. This situation has compelled academicians to switch over to elearning mode of getting education at most every level of education.

Which has also uplifted collaboration as well as social interaction (Shlossberg \& Cunningham, 2016; Wang, Pi, $\& \mathrm{Hu}, 2019)$. The COVID-19 has created an extremely challenging situation for education systems. The only way out is switching towards e-learning with customized models through the collaboration of teachers, students as well as educational institutions so that damage caused due to pandemic situation gets normalized (Daniel, 2020). E-learning also has created some challenges including familiarity with new e-learning applications, technical and cultural constraints (Shahmoradi et al., 2018). The main purpose of this research study is to examine the change in learning pedagogy in terms of switching over from conventional face to face classes towards e-learning. More specifically, this qualitative research study makes systematic review of COVID spillover and transition towards e-learning education pedagogy through theoretical framework. This research study integrates literature in the area in the following ways: Firstly, this study makes systematic review of transition towards e-learning. Secondly, this research study also studies the spillover effect of 
COVID on e-learning. Lastly, online collaborative learning (OCL) has been integrated in existing education modules for e-learning to avoid further damage to the education sector.

\section{Theoretical Framework}

In order to deal with COVID-19 pandemic situation, the major tools that can be used are isolation, social distancing and community containment. Further, on the basis of theoretical framework prepositions have been developed:-

Community Transmission: In community transmission the virus spreads quite speedily all over the world. It can take the form of community transmission especially in schools, universities and community places. This can be countered through social distancing and by following the standard operating procedures conveyed from time to time (Preiser, Van Zyl, \& Dramowski, 2020). The results of the study carried out on the association among school holidays and transmission of influenza also showed that school closure has positive impact on reduction of transmission especially influenza outbreaks (Jackson, Vynnycky, \& Mangtani, 2016).

Social Distancing: Social distancing is beneficial where chances of community transmission are on higher side. Closure of educational institutions, offices, markets and public places are the classical examples of social distancing (Wilder-Smith \& Freedman, 2020). In this critical situation; social distancing is the only way out by exclusion of functions, gatherings, closure of schools and universities. Further, with the blend of selfquarantine of travelers from high risk areas and self-isolation of symptomatic persons can reduce further transmissions (Preiser et al., 2020). Off course, the SOPs and e-learning modules do not change the pandemic situation but facilitate in attaining the objective of consistent level of education.

Securitization of Education Sector: The pandemic situation signifies the importance of Copenhagen securitization theory for education sector. In this critical situation, there is dire requirement to embed Copenhagen school securitization theory in education system. Furthermore, it is also required to do desecuritization of conventional schooling system. The same is also revealed by (Preiser et al., 2020).

Online Collaborative Learning (OCL): Online collaborative learning is among theories used for online learning by using internet. This theory was proposed by the Linda Haraism. It facilitates student as well educational institutions by using technology for collaboration and building knowledge base. It has reshaped methods of imparting formal as well as informal education (Harasim, 2017). The collaborative learning concept has advanced over the decades. Many programs have already switched to collaborative learning for group problem solving including education, management sciences and social sciences. Earlier logistics as well as time issues created problems, which are now addressed through internet and other forms of electronic communication. Moreover, wikis have also gained popularity and becoming quite famous vehicle for knowledge and content sharing (Fredericksen, 2015). In the critical pandemic situation online collaborative learning (OCL) has been used for e-learning to avoid further damage to the education sector.

\section{Propositions}

On the basis of theoretical framework, following prepositions have been developed:-

Assimilation of Technology and Education through E-Learning: Based on the literature and experiences, online teaching has become integral part of the forthcoming teaching methodology. Since the start of online learning in 2013, it has not become popular method not even in China. But during pandemic situation it has become quite popular. Moreover, online teaching has become quite useful tool for better understanding of concepts. Moreover, Professor Dehuan Liu of Chinese of Peking University also commented that the online classroom is the largest experiment in the history of forty years. Moreover, major universities are also collaborating with Ali Baba, Tencent education and other educational institutions to achieve assimilation of technology with the education (Zhou et al., 2020). Furthermore, it is also foreseeable that after commencement of normal routine face to face classes, the internet shall become an important medium for attaining education and clarity of concepts (Zhou et al., 2020). Therefore, internet usage has assimilated technology and education. 
Up Surging of Online Education Pedagogy during Pandemic Scenario: Based on experiences during pandemic, situation, it is prepositioned that e-learning has up surged especially during pandemic situation. Moreover, the trend of e-learning is on increase especially after pandemic situation (Demuyakor, 2020). Moreover, the same is also witnessed that higher (Wilder-Smith \& Freedman, 2020)education has been pushed towards e-learning at a mega scale (UNESCO, 2020). It was also forecasted that technology as well as pandemic situation shall reshape the universities by 2030 . The same has been experienced now a days and online education is considered effective method of teaching. The US department of education also revealed that students who take their classes online outperform conventional class room students in most of the subjects(Murphy, 2020). This situation has also compelled academicians to switch over to e-learning mode of getting education, which has also uplifted collaboration as well as social interaction (Shlossberg \& Cunningham, 2016; Wang et al., 2019). Before, the onset of pandemic situation in developing country like Pakistan, there were some e-learning applications designed to promote better concept building in students which includes Punjab e-learning, Sabaq foundation lectures and practice tests. Utilization of this facility requires provision of computer along with internet facility, which obviously is affected with the interruption in electric supply. They have proved as life line in engaging students without further waste of time. Therefore, based on above theoretical mechanisms we propose that upsurge of online education pedagogy has taken place especially during pandemic scenario.

\section{Conclusion and Recommendations}

This study has touched and highlighted the most critical education sector which has been severely affected due to pandemic situation created by the COVID-19 and its powerful spillover effect on education sector by customizing education pedagogy. This study makes systematic review of e-learning and spillover effect of COVID-19 and customization of the education pedagogy towards e-learning. In the exceptional circumstances of COVID-19, e-learning transition has taken place from conventional to e-learning modules. The result of the study shows that virus spreads quite speedily especially in community places including schools and universities. In this critical situation; social distancing is the only way out. This critical situation arise dire requirement to embed Copenhagen school securitization theory in education system. Likewise, (Murphy, 2020) also mentioned that securitization is significant tool for observation as well as understanding the phenomenon of emergency learning especially in COVID regime and desecuritization of schooling in post COVID crises period.

Online collaborative learning (OCL) has been used for e-learning to avoid further damage to the education sector. The study also reveals that assimilation of technology along with education sector has taken place in the shape of e-learning. All over the world, countries have also shifted towards online education by schooling out but classes in campaign ignited by Chinese government. The same has also been replicated in other countries of the world during COVID-19. The findings of this study also shows that pandemic situation has compelled academicians to switch over to e-learning model of getting education, which has also uplifted collaboration as well as social interaction. The study also shows that e-learning has also surged up at a mega scale especially during pandemic situation. The study provides insightful results for not only academicians as well as for students. This study also highlights that there is dire need to adopt counter checking of students getting online education, so that higher education standards can be maintained.

\section{References}

Daniel, S. J. (2020). Education and the COVID-19 pandemic. Prospects, 1-6.

Demuyakor, J. (2020). Coronavirus (COVID-19) and Online Learning in Higher Institutions of Education: A Survey of the Perceptions of Ghanaian International Students in China. Online Journal of Communication and Media Technologies, 10(3), e202018.

Fredericksen, E. (2015). Is online education good or bad? And is this really the right question. The Conversation.

Ghebreyesus, T. A. (2020). WHO Director-General's opening remarks at the media briefing on COVID-19-11 March 2020. World Health Organization. https://www. who. int/dg/speeches/detail/who-directorgeneral-s-opening-remarks-atthe-media-briefing-on-covid-19---11-march-2020.

Harasim, L. (2017). Learning theory and online technologies: Taylor \& Francis. 
Jackson, C., Vynnycky, E. \& Mangtani, P. (2016). The relationship between school holidays and transmission of influenza in England and wales. American journal of epidemiology, 184(9), 644-651.

Murphy, M. P. (2020). COVID-19 and emergency eLearning: Consequences of the securitization of higher education for post-pandemic pedagogy. Contemporary Security Policy, 1-14.

Ozili, et al. (2020). Spillover of COVID-19: impact on the Global Economy. Available at SSRN 3562570.

Preiser, W., Van Zyl, G. \& Dramowski, A. (2020). COVID-19: Getting ahead of the epidemic curve by early implementation of social distancing. SAMJ: South African Medical Journal, 110(4), 0-0.

Shahmoradi, L., Changizi, V., Mehraeen, E., Bashiri, A., Jannat, B. \& Hosseini, M. (2018). The challenges of Elearning system: Higher educational institutions perspective. Journal of education and health promotion, 7.

Shlossberg, P. \& Cunningham, C. (2016). Diversity, instructional research, and online education. Communication Education, 65(2), 229-232.

UNESCO. (2020). COVID-19 educational disruption and response. [Retrieved from https://en.unesco.org/covid19/educationresponse].

Wang, H., Pi, Z. \& Hu, W. (2019). The instructor's gaze guidance in video lectures improves learning. Journal of Computer Assisted Learning, 35(1), 42-50.

Wilder-Smith, A. \& Freedman, D. O. (2020). Isolation, quarantine, social distancing and community containment: pivotal role for old-style public health measures in the novel coronavirus (2019-nCoV) outbreak. Journal of travel medicine, 27(2), taaa020.

Zhou, L., Wu, S., Zhou, M. \& Li, F. (2020). 'School's Out, But Class' On', The Largest Online Education in the World Today: Taking China's Practical Exploration During The COVID-19 Epidemic Prevention and Control As an Example. But Class' On', The Largest Online Education in the World Today: Taking China's Practical Exploration During The COVID-19 Epidemic Prevention and Control As an Example (March 15, 2020). 